UDC 811.111:81'42

DOI 10.32999/ksu2663-3426/2019-1-23

\title{
PARATEXTUAL EPIGRAPH ELEMENTS (CASE STUDY OF STEPHEN KING'S NOVEL “CHRISTINE”)
}

\author{
Borysova Tetiana Serhiyivna, \\ Candidate of Philological Sciences, Associate Professor, \\ Associate Professor at the Department of Foreign Languages \\ Kherson State University \\ taipi13ram@bigmir.net \\ orcid.org/0000-0003-3023-5049
}

\begin{abstract}
The purpose of the article is to describe the stylistic potential of paratextual elements in the novel "Christine" by a modern American writer Stephen King. Methods. The descriptive method, as well as of structural-semantic and contextual analysis, allowed us to discover basic means of the paratextual elements conceptualization and define their functions. Results. It was determined that the epigraph is one of the paratextual elements that carries factual, conceptual and subtextual information in the novel under analysis, as well as introduces a significant layer of cultural information into the artistic space. Being closely related to the subtext and directly to the text of literary work, epigraphs promote a coherent reading of the novel since epigraphs bear an exact semantic projection of the artistic content of the corresponding text and act as a link between the chapters in the novel. The article presents a brief theoretical survey of the basic studies in this sphere in domestic and foreign linguistics; the main stylistic functions implemented by paratextual elements are identified. The study deals with the analysis of the composition and plot construction of Stephen King's novels, which resulted in a number of features specific to the author's novelistic techniques. Conclusion. The paratext was found to be an invariable element of Stephen King's works, comprising the title, epigraphs, short prefaces and dedications, and playing an important structural and meaningful role in artistic and semantic comprehension of the novel under analysis. Paratext in the novel is closely associated with the further text and serves as a clearly deliberate projection of its content and a reader's guide into this content.
\end{abstract}

Key words: paratextuality, paratextual elements, epigraph, projection of content, artistic and compositional organization.

\section{ЕЛЕМЕНТИ ПАРАТЕКСТУАЛЬНОЇ ЕПІГРАФИ (НА ПРИКЛАДІ РОМАНУ СТІВЕНА КІНГА «КРІСТІН»)}

\author{
Борисова Тетяна Сергіївна, \\ кандидат фрілологічних наук, доцент, доцент кафедри іноземних мов \\ Херсонський державний університет \\ taipi13ram@bigmir.net \\ orcid.org/0000-0003-3023-5049
}

\begin{abstract}
Mета статmі - описати стилістичний потенціал паратекстуальних елементів у романі «Крістіна» сучасного американського письменника Стівена Кінга. Методи. Дескриптивний метод, а також структурно-семантичний і контекстуальний аналіз дали змогу виявити основні засоби концептуалізації паратекстових елементів та визначити їхні фрункції. У дослідженні встановлено, що епіграфф є одним із паратекстуальних елементів, які містять в аналізованому романі фактичну, концептуальну й субтекстуальну інформацію, а також вносять у художній простір значний шар культурної інформації. Будучи тісно пов'язаними з підтекстом і безпосередньо з текстом літературної праці, епіграфри сприяють послідовному читанню роману, оскільки несуть точну семантичну проекцію художнього змісту відповідного тексту та виступають як зв'язок між розділами роману. Результати. У статті представлено короткий теоретичний огляд основних розвідок у сфрері дослідження паратексту у вітчизняній і зарубіжній лінгвістиці, визначено основні стилістичні фрункції, реалізовані паратекстуальними елементами. Дослідження містить також аналіз композиції та побудови сюжетів сукупності романів Стівена Кінга, що в результаті дало змогу визначити низку особливостей, характерних для наративної методики письменника, його ідіолекту. У висновках наукової розвідки зазначено, що паратекст є постійним елементом багатьох творів Стівена Кінга. Він складається з назви, епіграфів, коротких передмов, звернень і посвячень та відіграє важливу структурно-змістову роль у художньому й семантичному осмисленні аналізованого роману. Паратекст у романі тісно пов'язаний із подальшим текстом, є чітко обміркованим проектуванням його сюжетних ліній. Він не лише виконує функцію «керівництва», орієнтації читача на розуміння та сприйняття змісту твору, а й є коротким, проте ємним викладом естетичних поглядів і смаків письменника, що вказує на те величезне прагматичне значення, яке Стівен Кінг надає цій структурно-змістовій частині своїх романів, а також на художньо-смислову змістовність паратекстуальних елементів загалом.
\end{abstract}

Ключові слова: паратекстуальність, паратекстуальні елементи, епіграф, проекція змісту, художньо-композиційна організація. 


\section{Introduction}

Our work is devoted to the consideration of the relationship between the epigraph and the text of the novel "Christine" by Stephen King. An attempt has been made to review how the epigraph interprets the following text and prepares the reader for its perception. The importance of the information contained in the epigraph, is determined by its ability to disclose the overall meaningful plan of the work. At the same time, the available general background knowledge of the writer and readers is updated, relying on which, the author, through the purposeful selection of language units, intentionally influences the reader. This article is written in line with the scientific work on the theory of speech impact on the language community through written texts. Due to the fact that any text has a certain structure and specific communicative-pragmatic content, in our paper we have made an attempt to study not the text itself in its pure form, but the textual periphery, which has a pragmatic meaning. The study refers to the concept of "paratext", which appeared relatively recently in literary criticism and textology. Thus, the relevance of the research is substantiated by a small amount of study of paratext in comparison with the main texts of the literary works and their special role in the interpretation of the author's intention. The goal is to identify the communicative potential of an epigraph as a type of paratext and the ways of its language implementation, as well as to establish its functional significance on the material of Stephen King's novel "Christine". The descriptive method, as well as of structural-semantic and contextual analysis, allowed us to discover basic means of the paratextual elements conceptualization and define their functions.

\section{Analysis of recent research and publica- tions}

In modern literary studies the interest in elements that do not fully belong to the text of a literary work but, nevertheless constitute a whole, arose after the publication in 1987 of the work of the famous French researcher G. Genette "Seuils". The author understands by paratext some elements of a work of art that only partially belong to the text of the work itself, but at the same time constitute a single whole with it, which is called a book. According to the researcher, paratext is what allows a text to become a book and, as such, to offer it to readers and, more generally, to the general public (Genette, 1997). His ideas were continued by colleagues I. de Jong, C. Ashley, E. Tribble, P. Burke, S. Brown and others. G. Genette subdivides all paratextual elements into two broad categories: peritext and epitext. He calls such elements as the title and subtitle of the work, chapter headings, preface, notes, etc. - that is, in some sense you can find the text "inside". Epitext is more correlated with the "external" in relation to the text: an interview with the author, advertisements, reviews by critics, etc. Paratext is thus composed of a peritext and an epitext. In his book, G. Genette analyzes in detail various types of the publishing peritext, the meaning of the author's name (or lack thereof) on the cover of the work, the role, types and functions of headings, epigraphs, initiations, notes, the value of supercovers, as well as public and private epithexes.

The category "paratextuality" is the relationship of the text to its title, afterword and epigraph. The epigraph can serve as a comment to the title of the text, or it can function as a key word-password necessary for understanding the historical, cultural and biographical contexts associated with the author (Genette, 1997: 145-149). It reflects the ability of the paratextual element to interact with different levels of text. Paratextuality was also presented in the classification of G. Genette in the book "Palimsestes: la litterature au second degree". Paratextuality completes the text and transforms it into a product that is already in the hands of the reader. It is believed to be a special zone between text and non-textual reality, which is intended for direct impact on the reader (Genette, 1982).

Paratext elements take a strong position in the text, since they are separated from the main text and communicatively completed. In the terminology of N. Kuzmina, such elements are "extremely powerful energy signs", in which the presence of the author is always noticeable and thanks to which the author implicitly broadcasts meaningful information for him. An important function of paratextual elements is informative. As a rule, paratexts introduce some information about the text following them: they set the theme of the work, outline the leitmotifs of individual parts, reveal the concept of the work, update the semantic dominant of the text, or enter some subtext information, while indicating the author's attitude to it. Paratext is a mask behind which the author hides, when he, not wanting to speak directly, indirectly determines his attitude to the events depicted by him in the work. In addition, he is able to set the form, language, stylistic structure of the subsequent work. So, paratextual elements, "on the one hand, reveal the author's intention, on the other hand, form the reader's presupposition, create pragmatic conditions for understanding 
the text as a metatext" (Kuzmina, 2004: 151) According to this concept, there is a division of the text into two levels: deep and superficial. At the same time, the deep level has the character of coding meaning and is represented by such logical-semantic concepts as an invariant, a semantic core, a central link and a semantic node. The surface layer decodes the elements of the deep level with the help of variable expansion, background, periphery and context. The functional semantic dependence, by means of which the content of the speech situation is selected in the microthematic, thematic, macrothematic and textological plans, combines the elements of the deep and superficial levels, creating the text as a decoded unit of written speech (Kuzmina, 2004).

In modern science, there is a certain amount of research devoted to the study of the epigraph, its functional purpose in the text, the typological classification, the role it plays in the perception of the text by the reader, and other features of it. Traditionally, most works are based on the positions of literary criticism (S. Bocharov, G. Gukovsky, Y. Ivakin, E. Kirilyuk, S. Krzhizhanovsky, N. Kuzmina, A. Kulagin, Yu. Lotman, A. Tkachenko, B. Shklovsky). On the semantics of epigraphs I. Arnold, N. Zhirmunskaya, O. Popova, A. Khramchenkov, G. Chumakov and others paid attention. An epigraph is an element or component of a text that not only predicts upcoming novel events and sets the reader to their specific perception, but also becomes one of the artistic means of creating meaningful completeness. L. Ginzburg noted: "Other people's words are always a find - they are taken as they are: they still cannot be improved or redone. "Alien words", even if remotely and inaccurately expressing our thought, act as a revelation or as a long-sought and found formula. Hence the charm of epigraphs and quotations" (Ginzburg, 1979). Z. Turaeva defines an epigraph as "that component of a literary text that sends the reader to the source text and programs the network of associations that mark of artistic text that is able to establish intrasemiotic correspondences" (Turaeva, 1986: 54). The epigraph has two directions - the source text and the quoting text, therefore its semantics is located at the intersection of the inline and extratext structures.

The basic features of the epigraph are its dialogue, intertextuality and aesthetic, ideological and thematic) functions (Arnold, 2004: 8). Due to the indicated features, the relationship between the text and its epigraph is of great interest for our research, where an epigraph is considered as a fragment of another discourse, influencing the perception and interpretation of the modern literary text. The relationship between the text and its epigraph can also be viewed from the perspective of hermeneutics. Under the hermeneutics of the epigraph I. Arnold understands two aspect of its interpretation: "Firstly, it should be understood as a quotation, as part of the case text, i.e. interpreted as hermeneutic object, and, secondly, it itself interprets the text to which it precedes and turns out to be the subject of interpretation". In this way, an epigraph can act as a subject of interpretation of following text. The compactness of the epigraph defines it synthesizing function in relation to the main text (Arnold, 2004: 9). Synthesizing is the common function of the epigraph under consideration is that its distinguished elements are the main indicators contained in the subsequent text of the meanings about which the epigraph first informs the reader, thus influencing its interpretation. Others epigraph meanings contained in the text conflict with the meanings of the following text. Thus, the epigraph highlights the most important elements of the content, informs the reader about the author's attitude to this problem.

\section{Statement of the base material}

Thus, we can suppose that the epigraph contributes to the formation of (in this case - the same as the author) opinions from the reader on relation to the facts described in the subsequent text of the chapter. The choice of the writer of the epigraph depends on the level of education of the author, his literary preferences, such as artistic thinking, style, genre and design work. It is clear that by introducing such an optional element, the author attaches great importance to it. The epigraph often serves as a key to understanding the artistic concept, expresses the main conflict, theme, idea or mood of the work, helping to perceive it, and also denotes the associative connections of the work with literary tradition and modernity. The epigraph takes an autonomous position, serves as a means of expressing author's intentions, the pragmatic attitude of the author. For the formation of the reader installation, not only the epigraph is important, but also its origin: temporal, spatial, sociocultural, remoteness of the source. Most often, the source of the epigraphs are various precedent texts: folklore sources, biblical and religious writings, artistic texts. Both titles and epigraphs allow different interpretations, and their interpretation is probabilistic stochastic, and not rigidly deterministic process (Turaeva, 1986: 54).

Among the main functions of an epigraph it is possible to distinguish: 
1) marking: the epigraph has a specific location in the text - graphically separated from the text is in front of it and plays the role of a marker in it;

2) transference of literary tradition;

3) theme defining;

4) content-factual: the epigraph indicates that the information about the text can be differentiated into meaningful and formal levels;

5) referential: a quotation taken as an epigraph, and a citation signal are of the same nature, since they are always referred to a specific source text;

6) creating aesthetic interaction of texts: a quotation from another text transfers the role of the aesthetic intermediary;

7) integrating: epigraphs testify to the integration of cultural traditions of different eras, they create different contexts, develop storylines, reflect the poet's literary or historical and cultural views;

8) dialogizing: an epigraph is one of the ways of dialogizing a monologue, introducing into it another, non-authorial point of view; the dialogical relations of the epigraph and the text following it can be explicated and implicit; the nature of the dialogue reveals the communicative intention of the author, his attitude to the content of the epigraph and to its creator;

9) subject-informative: the information presented in the epigraph may be of two types: information about the author (creative subject), choosing an epigraph from a certain literary and cultural paradigm, and information about the text following the epigraph. Subject information contains information about the author, his literary tastes, and communicative intent in this text. A certain part of the subject information arises already at the moment when the writer chooses an epigraph, the other - only in the process of its functioning. The subject information arising at the moment of choosing an epigraph is concretized, specified in the complex "epigraph - text";

10) form-building and form-determining: an epigraph reports the form (language) of the text entered by it. Informing about the form, he, in fact, sets this form, generates;

11) subtext: the epigraph creates internal overtones;

12) stylistic: the epigraph defines keywords and theses, forms the stylistic and emotional tonality of the text.

As we see, the epigraph sets the theme, defines the idea and the concept of a work of art, which is perceived and developed by the text following it, and thus actualize the semantic dominant of the text and is its evaluative criterion. In terms of the interpretation and literary and the stylistic analysis of the text, the epigraph has a special value, being an expression of the author's position, a paratextual element containing the direct author's message. Intra-text functions of the title and epigraph indicate their relationship with the text, determine the main theme or idea works, give the key to understanding the author's intention. The essence of the value of the epigraph for decoding the author's intention very clearly defined in the statement of I. Arnold: "Itself the lack of presence of the epigraph makes it especially informative if there is one" (Arnold, 1978: 27).

As we have already stated, the material of our thesis is the novel by S. King "Christine". In the structure of the composition of the overwhelming part of King's novels, an important role belongs to the paratextual complex, which includes such aesthetically significant elements as the name of the novel, epigraph, dedication or dedication-appeal to the reader, notification, that is, everything that is called paratext in narratology. The analysis of the compositional and plot construction of the totality of King's novels revealed a number of feature characteristics of his novel technique. The novel "Christine" consists of 51 chapters and 50 of them are preceded by a musical quote from rock hits, they are about love and cars, about friends and cars, about love of cars and so on. In combination with the general rollick, they create a unique atmosphere. Each epigraph placed at the beginning of each part of "Christine" is closely connected with both the name of the part and its content. For example, the epigraph to the first chapter "FIRST VIEWS" contains the words from Eddie Cochran's song:

Hey, looky there!

Across the street!

There's a car made just for me,

To own that car would be a luxury.

That car's fine-lookin, man,

That's somethin else.

This epigraph totally corresponds with the events in the chapter: the main character Arnold "falls in love" with the old car he saw in the street. His friend comments that "He was gone, lock, stock, and barrel. Arnie had fallen in love... Arnie had fallen in love with a 1958 Plymouth Fury, one of the long ones with the big fins".

The following quote that precedes the second chapter THE FIRST ARGUMENT is from a famous song "Yakety-Yak" by The Coasters:

Just tell your hoodlum friends outside,

You ain't got time to take a ride!

(yakety-yak!)

Don't talk back! 
It reflects Arnie's parents' authoritative attitude to their son and to his decision to buy an old car, which is stated by his friend in the text of the second chapter as: "His folks knew it as well as the machine-shop white-soxers who yelled at him in the halls and thumb-rubbed his glasses. They knew he was a loser and they would beat him down. That's what I thought". The epigraph looks like a part of a real conversation between the main character and his "folk", thus reinforcing the impression from the events described in the novel.

The paratextual element of the third chapter that contains the words from Charlie Ryan's song "Hot-rod Lincoln" continues the theme of generation gap and parents-teenagers relationships:

My poppa said "Son,

You're gonna drive me to drink

If you don't quit drivin that

Hot-rod Lincoln".

Later in this chapter, one of characters echoes the message of the song: "I think that part of being a parent is trying to kill your kids. "That sounds very rational", I said. "Mine are always trying to kill me. Last night it was my mother sneaking in with a pillow and putting it over my face. Night before that it was Dad chasing my sister and me around with a screwdriver".

The epigraph to the chapter "ARNIE GETS MARRIED" also predetermines fantastic events of the following text:

I remember the day

When I chose her over all those other

junkers,

Thought I could tell

Under the coat of rust she was gold,

No clunker...

The author has chosen the lyrics of one of his favourite American groups The Beach Boys "This car of mine", where the car is compared with a girlfriend: "I never want to part with her, you see. This little car means a heck of a lot to me..." In the chapter we see the similar example of personification as the car for the first time shows itself to the main characters like some live creature and even starts to speak with them:

I put my hands on the wheel and something happened.

Even now, after much thought, I'm not sure exactly what it was. A vision, maybe - but if it was, it sure wasn't any big deal. It was just that for a moment the torn upholstery seemed to be gone. The seat covers were whole and smelling pleasantly of vinyl $<\ldots>$ or maybe that smell was real leather. The worn places were gone from the steering wheel; the chrome winked pleasantly in the summer evening light falling through the garage door.

Let's go for a ride, big guy, Christine seemed to whisper in the hot summer silence of LeBay's garage. Let's cruise.

Thus, having analyzed the functions of the epigraphs in the novel "Christine", we can conclude about their influence on the genre attribution of works as well as the importance of intra-textual links (links between epigraphs), contributing to the coherent and holistic reading of the text.

\section{Conclusions}

The constant element of the composition of S. King's novels is paratext, which contains the title of the work, epigraphs, short prefaces and initiations, and plays an important structural and substantive role, since it sets the perspective of an ideological and semantic interpretation of the work. The analysis revealed that all the epigraphs are just as important in the artistic system of later novels as the names, since they are the exact semantic projection of the ideological and artistic content of the corresponding novel and act as a kind of connection between its name and text. Epigraphs in "Christine" are a kind of text in the text, and not just quotes, prefaced to the entire text or parts of it. They are one of the artistic means of creating meaningful completeness. The choice of the quotation for the epigraph was not accidental; the novelist compared or pushed different views on the depicted. Directing the reader with an epigraph to a particular event, the writer creates an internal subtext that prepares for the perception of the book. Artistically conditioned and significant epigraphs can be considered as allusions, hints to the idea of the novel, to the turning points of the plot, to the main characters.

\section{BIBLIOGRAPHY:}

1. Арутюнова Н.Д. Проблемы морфологии и словообразования. Москва : Языки славянской культуры, 2007. $286 \mathrm{c.}$

2. Арнольд И.В. Герменевтика эпиграфа. Слово Высказывание - Дискурс : международный сборник научных статей / под ред. А.А. Харьковской. Самара : Самарский университет, 2004. С. 8-15.

3. Genette G. Palimsestes: la litterature au second degree. Paris : Éditions du Seuil, 1982. 467 p.

4. Genette G. Paratexts: thresholds of Interpretation. Cambridge : Cambridge University Press, 1997. 427 p.

5. Гинзбург Л.Я. О литературном герое. Ленинград, 1979. $223 \mathrm{c}$.

6. King S. Christine. URL: http://avidreaders.ru/read-book/ christine.html (access date: 27.04.2019).

7. Кузьмина Н.А. Интертекст и его роль в процессах эволюции поэтического языка. Москва : Едиториал УРСС, 2004. 267 C. 
8. Папина А.Ф. Текст: его единицы и глобальные категории. Москва : Едиториал УРСС, 2002. 368 с.

9. Тураева 3.Я. Лингвистика текста. Москва : Просвещение, 1986. 127 с.

\section{REFERENCES:}

1. Arutiunova, N.D. (2007). Problemy morfologii i slovoobrazovaniia [Problems of morphology and word formation]. Moscow: lazyki slavianskoi kultury [in Russian].

2. Arnold, I.V. (2004). Germenevtika epigrafa [Hermeneutics of the epigraph]. Slovo - Vyskazyvanie - Diskurs: mezhdunarodnyi sbornik nauchnykh statei. Samara: Samarskii universitet, pp. 8-15 [in Russian].

3. Genette, G. (1982). Palimsestes: la litterature au second degree [Palimpsestes: the second degree literature]. Paris: Éditions du Seuil [in French].
4. Genette, G. (1997). Paratexts: thresholds of Interpretation. Cambridge: Cambridge University Press [in English].

5. Ginzburg, L.la. (1979). O literaturnom geroe [On the literary hero]. Leningrad [in Russian].

6. King, S. (1983). Christine. URL: http://avidreaders.ru/readbook/christine.html [in English].

7. Kuzmina, N.A. (2004). Intertekst i ego rol v protsessakh evoliutsii poeticheskogo iazyka [Intertext and its role in the evolution of poetic language]. Moscow: Editorial URSS [in Russian].

8. Papina, A.F. (2002). Tekst: ego edinitsy i globalnye kategorii [Text: its units and global categories]. Moscow: Editorial URSS [in Russian].

9. Turaeva, Z.la. (1986). Lingvistika teksta [Text linguistics]. Moscow; Prosveshchenie [in Russian].

\title{
MODERN UKRAINIAN TRENDS IN THE STUDY OF THE TRANSLATOR'S PERSONALITY INFLUENCE ON THE TRANSLATION PROCESS
}

\author{
Volchenko Olha Mykhailivna, \\ Candidate of Pedagogical Science, \\ Associate Professor at the Department of German Philology and Translation \\ Mykolaiv V. O. Sukhomlynskyi National University \\ volchenkoom@ukr.net \\ orcid.org/0000-0002-8519-4531 \\ Ababilova Nataliia Mykolaivna, \\ Candidate of Pedagogical Science, \\ Associate Professor at the Department of German Philology and Translation \\ Mykolaiv V. O. Sukhomlynskyi National University \\ ababilovann@gmail.com \\ orcid.org/0000-0002-9454-6674
}

Translator's personality, the influence of his consciousness and the subjective choice on the translation process and result are attracting more interest nowadays as translation studies are going beyond the scope of the language-centered studies. The aim of the article is to analyze the Ukrainian scholars' views on the effect of the translator's personality on the presentation of the foreign language culture and the development of literally contacts among the peoples. The complex and integrative nature of the study produces the use of interacted methods. The general scientific methods of analysis and synthesis were used for: studying theoretical basis of translators' creative personal characteristics not only in translation, but in related sciences; generating hypotheses, concepts, models, etc. The inductive method made it necessary to generalize the material and conclusions on the basis of the existing study. The deductive method was in use while adapting the principles of the general translation theory in the aspect of the suggested investigation, a pair of the involved languages, genre and style and functional varieties of the texts and/or their constituents. Classification and typological analysis was used to regulate and represent the studied material in the form of classifications and typologies. A translator as a participant of speech activity has a number of characteristics: linguistic, social, philosophical, psychological. They are interacted and influence each other. The translator's personality as a cultural mediator still remains the driving force of intercultural relations and influences significantly the translation adequacy. The translator performs two tasks at the same time. On the one hand, he/she should save the contents of the source language message, taking into account its form specifics, and on the other hand, he/she tries to represent their identity details by creating the equivalent/adequate target language text. The study of the translator's personality influence on the process and the result of the translation has broad prospects just today, as Ukraine is experiencing an incredible increase of translations in foreign languages not only of foreign authors but also Ukrainian ones. This process involves experienced translators as well as beginners who are still developing their own individual interpretative approach.

Key words: translator's features, linguistic persona, translator's creativity, translation strategies, interpretation. 